STUdIA KATECHETYCZNE - tom 17/2021

DOI https://doi.org/10.21697/sk.2021.17.12

\author{
KS. RAFAŁ BEDNARCZYK \\ UKSW WARSZAWA \\ ORCID 0000-0002-4486-7664
}

\title{
ODNOWA KATECHEZY WOBEC EWANGELIZACJI I NAWRÓCENIA DUSZPASTERSKIEGO
}

Odnowa katechezy jest jednym z ogniw reformy Kościoła, która została zapoczątkowana w trakcie obrad II Soboru Watykańskiego. Obejmowała i nadal obejmuje ona przede wszystkim różne aspekty jego aktywności pastoralnej, zmierzając z jednej strony do coraz lepszego zrozumienia współczesnego świata i związanych z nim wyzwań, zaś z drugiej - do powrotu do źródeł pierwotnej żywotności Kościoła. Obydwa kierunki odnowy katechezy przyczyniają się do jej rozwoju i podnoszenia skuteczności. Doświadczenia ostatnich dekad, w czasie których podejmowany jest stale ów wysiłek odnowy, nie dają poczucia sukcesu. Globalne zmiany cywilizacyjne, laicyzacja życia młodzieży, kryzys instytucji Kościoła - zwłaszcza ostatnio związany z licznymi oskarżeniami, ofensywa środowisk reprezentujących ideologię lewicowo-liberalną, promowanie aktów apostazji oraz ataki na chrześcijan to tylko wybrane czynniki zewnętrzne, które osłabiają skuteczność katechezy. Analogicznie można wskazać trudności wewnętrzne Kościoła, obniżające jej efektywność, jak kryzys powołań kapłańskich i do życia zakonnego, implozja rodziny jako środowiska przekazu wiary i wartości religijnych, zanik więzi wspólnotowych w parafiach, małe zainteresowanie młodzieży formacją $w$ grupach parafialnych. Nadal jeszcze cieszymy się, że w Polsce na religii w szkole wciąż jeszcze mamy większość młodzieży ${ }^{1}$, jednak nie przekłada się to na poziom ich praktyk religijnych.

Poszukując dróg odnowy katechezy trzeba także odróżnić to pojęcie od lekcji religii. Obecnie w Polsce wysiłek Kościoła koncentruje się na katechizacji w szkole, która jest de facto lekcją religii. Tenże obraz najwyraźniej widać w dużych miastach. W mniejszych ośrodkach, gdzie powiązania pomiędzy szkołą a parafią są silniejsze, lekcja religii bardziej przekłada się na życie religijne dzieci. Dotyczy to jednak niemal wyłącznie szkół podstawowych, ale i w tym obszarze daje się dostrzec

\footnotetext{
1 Według danych opublikowanych 1.09.2020 r. na stronie Katolickiej Agencji Informacyjnej eKAI w roku szkolnym 2019/2020 na lekcje religii uczęszczało w Polsce 87,6 \% uczniów. Rok wcześniej było ich $88 \%$ (94,2 \% w szkołach podstawowych i nieco ponad $80 \%$ w szkołach ponadpodstawowych). Najniższą frekwencję zanotowano w archidiecezji warszawskiej - 74,8\%, łódzkiej - 77,7\% i diecezji sosnowieckiej - 75,2\%, w: https://www.ekai.pl/nauczanie-religii-w-polsce/ (dostęp 1.03.2021).
} 
proces rozdzielania edukacji szkolnej od parafii. Równocześnie trudno jest mówić o istnieniu katechezy parafialnej, która ogranicza się w zasadzie do przygotowania przedsakramentalnego - do I Komunii Świętej, bierzmowania, sakramentu małżeństwa i niekiedy jeszcze przez sakramentem chrztu św. Bez jej ożywienia proces odnowy katechezy nie przyniesie oczekiwanych owoców.

Dla przezwyciężenia nakreślonych powyżej kryzysów, z którymi boryka się współczesna polska katecheza, od lat próbuje się szukać szansy w rozwijaniu idei ewangelizacji i nowej ewangelizacji. Chociaż samo słowo „ewangelizacja” posiada korzenie biblijne, jednak stało się ono synonimem odnowy katechezy w XX w. W działalności ewangelizacyjnej główny akcent kładzie się na głoszenie Jezusa Chrystusa, wzbudzanie wiary w Niego i wzywanie do nawrócenia ${ }^{2}$. Niniejsze opracowanie stanowi próbę spojrzenia przekrojowego na rozwój idei ewangelizacji w obrębie nauczania ostatnich papieży i dokumentów katechetycznych Kościoła. W świetle przeprowadzonej refleksji będzie możliwe lepsze odczytanie zadań, jakie na tym polu stają przed współczesną katechezą.

\section{Ewangelizacja $w$ nauczaniu papieży}

Idea ewangelizacji zapoczątkowana w obecnym kształcie przez św. Pawła VI miała stanowić odpowiedź na postępujący w świecie proces laicyzacji i dechrystianizacji. Od tego czasu ewangelizacja, a następnie nowa ewangelizacja stały się słowami wyznaczającymi określony horyzont działalności pastoralnej Kościoła. Pierwotnie ewangelizacja oznaczała działalność apostolską skierowaną do osób niewierzących, znajdujących się poza granicami Kościoła. W tym sensie był on na ogół stosowany w dokumentach II Soboru Watykańskiego i odnoszony do aktywności misyjnej Kościoła ${ }^{3}$. Wprawdzie można także dopatrzeć się w tekstach soborowych ukierunkowania ad intra (do członków Kościoła), jednak zostało ono szerzej rozwinięte dopiero przez św. Pawła VI w adhortacji Evangelii nuntiandi. Bez ewangelizacji samego siebie - zauważa papież - Kościół nie będzie w stanie prowadzić ewangelizacji wśród osób nieznających Chrystusa ${ }^{4}$.

W omawianym dokumencie znajdujemy także pogłębioną wykładnię tego terminu. Na pierwszym miejscu papież wskazuje na zadanie głoszenia Chrystusa tym, którzy Go nie poznali ${ }^{5}$. Następnie przechodzi do spojrzenia na ewangelizację

\footnotetext{
2 Zob. R. Murawski, Stosunek ewangelizacji do katechezy w dziejach katechezy, w: S. Dziekoński (red.), Ewangelizować czy katechizować?, Warszawa 2002, s. 12-15.

3 Por. B. Biela, Typy i metody ewangelizacji w świetle wspótczesnego nauczania Magisterium Ecclesiae, „Studia Nauk Teologicznych” 10(2015), s. 260-261, w: https://czasopisma.kul.pl/snt/article/ view/6257/5860 (dostęp 1.03.2021); G. Puchalski, Ewangelizacja i nowa ewangelizacja w nauczaniu Kościoła, w: P. Mąkosa (red.), Katecheza ewangelizacyjna. Poszukiwania koncepcji, Lublin 2021, s. 17. 4 Zob. Paweł VI, Evangelii nuntiandi, 15.

5 Zob. tamże, 17.
} 
rozumianą jako docieranie z Dobrą Nowiną do szerokich kręgów ludzkości w celu poruszenia ich do wewnętrznej przemiany ${ }^{6}$. Należy zatem tu widzieć działanie polegające na wnoszeniu wartości ewangelicznych w życie świata, a w tym tworzenie kultury opartej na Ewangelii (inkulturacja) ${ }^{7}$. Za terminem ewangelizacja kryje się rzeczywistość złożona i dynamiczna, która ma swe źródło w działaniu Ducha Świętego. Dla zrozumienia tego terminu istotną rolę odgrywa rozróżnienie adresatów ewangelizacji. W pierwszym rzędzie są nimi nieznający Chrystusa, następna grupa to chrześcijanie potrzebujący pomocy w umacnianiu swojej wiary oraz osoby, które już nie są chrześcijanami przez wybór życia niezgodnego z Ewangelią․ Uprzywilejowanym narzędziem ewangelizacji jest świadectwo dawane życiem jako droga naśladowania Chrystusa w ubóstwie, wstrzemięźliwości, wolności od pokus i rządzy władzy. Świadectwu powinien towarzyszyć również dialog w atmosferze miłości oraz przepowiadanie Ewangelii z wezwaniem do nawrócenia i przemiany życia ${ }^{9}$.

Kolejnym papieżem, który podjął problematykę ewangelizacji w działalności Kościoła, był św. Jan Paweł II. To on wprowadził obok dotychczasowego terminu ewangelizacja również jego rozwinięcie - nowa ewangelizacja. Papież określenie ewangelizacja używał w odniesieniu do działalności misyjnej, co znalazło swoje odbicie w encyklice Redemtoris missio ${ }^{10}$. Dodając do niego przymiotnik nowa, wprowadził nowe znaczenia tego terminu uznając, że odnosi się ono do wszystkich chrześcijan, ponieważ cały Kościół potrzebuje ponownej ewangelizacji. Papież widział to w perspektywie procesów cywilizacyjnych i stylu życia wielu uczniów Chrystusa, który w niewielkim stopniu odpowiada zasadom zawartym w Ewangelii. Nowa ewangelizacja oznacza powrót do Ewangelii jako źródła życia, przylgnięcie do wspólnoty Kościoła, zakorzenienie w sakramentach oraz rozwinięcie postawy miłości i pokornej służby braciom ${ }^{11}$. Nowość w tym wypadku nie odnosi się do treści, która jest ta sama, ale do działania Ducha Świętego w życiu chrześcijan, ponieważ często ich wiara stygnie, traci swoją wyrazistość i przestaje być świadectwem wierności Ewangelii. W wypowiedziach św. Jana Pawła II wybrzmiewało wezwanie do tego, by nowość ewangelizacji wyraziła się przede wszystkim w nowym zapale, metodach i wyrazie ${ }^{12}$. To dość ogólne sformułowanie dawało jednocześnie swobodę $\mathrm{w}$ interpretacji istoty nowej ewangelizacji. Ważne na tym polu było podkreślenie,

\footnotetext{
6 Por. tamże, 18.

7 Por. G. Puchalski, Ewangelizacja i nowa ewangelizacja..., art. cyt., s. 17-18.

8 Por. B. Biela, Typy i metody ewangelizacji ..., art. cyt., s. 261-262.

9 Por. Paweł VI, Evangelii nuntiandi, 21-26, 41; G. Puchalski, Ewangelizacja i nowa ewangelizacja..., art. cyt., s. 19.

10 Zob. P. Tomasik, Ewangelizacja-katecheza-nauczanie religii w szkole, w: Ewangelizować czy katechizować?, dz. cyt., s. 27-28.

11 Zob. G. Puchalski, Ewangelizacja i nowa ewangelizacja..., art. cyt., s. 21-22.

12 Zob. A. Lewek, Idea i sens nowej ewangelizacji, „Studia Theologica Varsaviensia” 32(1994)2, s. $46-48$.
} 
że podmiotem nowej ewangelizacji jest cały Kościół, zaś krąg adresatów obejmuje wszystkich, których wiara jest nadwątlona i oddalona od praktyki życia (ochrzczeni a nie praktykujący; ludzie pobożności ludowej posiadający słabe ugruntowanie; ludzie wykształceni o niskim poziomie wiary; chrześcijanie ukrywający swoją tożsamość). Wyraził to papież w adhortacji Ecclesia in Europa z 2003 roku:

Wielu współczesnych Europejczyków sądzi, że wie, co to jest chrześcijaństwo, ale w rzeczywistości go nie zna. Często nawet podstawy i najbardziej zasadnicze pojęcia chrześcijaństwa nie są już znane. Wielu ochrzczonych żyje tak, jakby Chrystus nie istniał; powtarza się gesty i znaki związane $\mathrm{z}$ wiarą, zwłaszcza w praktykach religijnych, ale nie odpowiada im rzeczywista akceptacja treści wiary i przylgnięcie do Osoby Jezusa. Miejsce pewności wielkich prawd wiary u wielu ludzi zajęło niejasne i mało zobowiązujące uczucie religijne; szerzą się różne formy agnostycyzmu i praktycznego ateizmu, które przyczyniają się do pogłębienia rozdźwięku między wiarą a życiem; wielu uległo duchowi immanentystycznego humanizmu, który osłabił ich wiarę, prowadząc niestety często do jej całkowitego porzucenia; jesteśmy świadkami swego rodzaju sekularystycznej interpretacji wiary chrześcijańskiej, która powoduje jej erozję i z którą wiąże się głęboki kryzys sumienia i praktyki moralności chrześcijańskiej ${ }^{13}$.

Ludzie Kościoła mają być otwarci na znaki czasu i działanie Ducha Świętego, który jest głównym architektem tego dzieła. Św. Jan Paweł II szczególną rolę w nowej ewangelizacji przyznawał świeckim, którzy przez świadectwo swego życia, budowanie małych wspólnot wiary oraz rozwijanie kultury opartej na wartościach ewangelicznych będą w stanie przeciwstawiać się agresywnej sekularyzacji i dechrystianizacji. Miała ona także przyczyniać się do budowania cywilizacji miłości, a zatem afirmacji życia, godności każdego człowieka, jego praw, sprawiedliwości społecznej, wsparcia na rzecz ubogich oraz sprawiedliwego podziału dóbr. Papież doceniał także rolę nowoczesnych środków komunikacji społecznej w szerzeniu ewangelizacji. Bez wykorzystania najnowszych narzędzi komunikacji oddziaływanie Kościoła w świecie pozostanie ograniczone ${ }^{14}$.

W dziejach nowej ewangelizacji kolejne karty zapisał papież Benedykt XVI. Kontynuując pracę swoich poprzedników podjął starania o instytucjonalne wzmocnienie tego dzieła, powołując w 2010 roku Papieską Radę ds. Krzewienia Nowej Ewangelizacji. Wydany $\mathrm{z}$ tej racji list w formie motu proprio Ubicumque et semper określał główne zadania Rady:

13 Jan Paweł II, Ecclesia in Europa, 47.

14 Zob. tamże, s. 49-52; G. Puchalski, Ewangelizacja i nowa ewangelizacja..., art. cyt., s. 25-28; W. Śmigiel, Specyfika i zadania nowej ewangelizacji, w: P. Mąkosa (red.), Nowa ewangelizacja w nowej katechezie, Lubin 2013, s. 16-17; P. Tomasik, Ewangelizacja-katecheza-nauczanie religii w szkole, art. cyt., s. 31-33. 
- pogłębianie teologicznego i duszpasterskiego znaczenia nowej ewangelizacji;

- $\quad$ promowanie i popieranie, w ścisłej współpracy z konferencjami episkopatów, które będą mogły posiadać struktury ad hoc, studium, szerzenia i wprowadzania w życie papieskiego Magisterium odnoszącego się do tematów związanych z nową ewangelizacją;

- upowszechnianie i wspieranie inicjatyw związanych z nową ewangelizacją, realizowanych w różnych Kościołach partykularnych, i promowanie nowych, z udziałem sił obecnych w Instytutach Życia Konsekrowanego i Stowarzyszeniach Życia Apostolskiego, jak również w stowarzyszeniach wiernych i w nowych wspólnotach;

- studiowanie i wspieranie wykorzystywania nowoczesnych form przekazu, jako narzędzi nowej ewangelizacji;

- $\quad$ promowanie posługiwania się Katechizmem Kościoła Katolickiego jako zasadniczym i pełnym wykładem treści wiary dla ludzi naszych czasów ${ }^{\mathbf{1 5}}$.

W podjętej przez Benedykta XVI inicjatywie widać troskę o lepszą koordynację działań na polu ewangelizacyjnym oraz wzbogacanie ich przez refleksję teologiczną. Ojciec Święty duże znaczenie przywiązywał do narzędzia, jakim jest Katechizm Kościoła Katolickiego, co było wprost związane z pogłębiającą się wśród chrześcijan nieznajomością prawd wiary bądź z ich negowaniem ${ }^{16}$. Takie powiązanie wskazywało na potrzebę głębszej koordynacji ewangelizacji z katechizacją, aby człowiek przyjmujący wiarę w Chrystusa mógł się także zapoznać z pełnym zakresem prawd, którymi żyje Kościół. Celem powstania Rady nie było biurokratyzowanie nowej ewangelizacji, ale kreowanie poszerzonej i długofalowej wizji jej działań. Papież konsekwentnie przy tym podkreślał, że u podstaw nowej ewangelizacji znajduje się spotkanie z osobą Jezusa Chrystusa, który przynosi człowiekowi prawdę o nim i o jego ostatecznym przeznaczeniu. Z tym spotkaniem wiąże się doświadczenie Bożej miłości i wprowadzenie w głęboką, intymną więź z Panem, dzięki której człowiek jest w stanie przemieniać swoje życie, wybierając drogę duchowej wolności. Benedykt XVI przypominał w tym kontekście kluczową rolę, jaką w tym dziele odgrywa Duch Święty ${ }^{17}$.

Obecny następca św. Piotra - papież Franciszek - ewangelizację czyni jednym z priorytetów swojego pontyfikatu. Można mówić, iż jego adhortacja Evangelii gaudium o głoszeniu Ewangelii w dzisiejszym świecie ma charakter programowy i przynosi nowe spojrzenie na rzeczywistość nowej ewangelizacji ${ }^{18}$. Bazując na nauczaniu

15 Benedykt XVI, Ubicumque et semper, 3.

16 Zob. W. Osial, Wezwanie Benedykta XVI do nowej ewangelizacji wświetle listu apostolskiego „motu proprio" Ubicumque et semper ustanawiajacego Papieską Radę Ds. Krzewienia Nowej Ewangelizacji, „Warszawskie Studia Teologiczne” 24(2011)1, s. 286-288.

17 Por. tamże, s. 284-286; S. Tokarek, Ewangelizacja według Benedykta XVI, „Studia Teologiczno-Historyczne Śląska Opolskiego" 2013, s. 252-253.

18 Trzeba jednak zaznaczyć, iż papież Franciszek w zasadzie nie stosuje rozróżnienia na ewangelizacje i nowa ewangelizację. W dokumencie zaledwie kilka razy używa zwrotu nowa ewangelizacja. Jednak 
i dokonaniach swoich poprzedników wnosi jednocześnie własne doświadczenia duszpasterskie związane z życiem Kościoła w Ameryce Łacińskiej. W swoich wypowiedziach dąży do radykalizowania działań duszpasterskich, stosując wezwanie do nawrócenia pastoralnego. Kładzie zatem punkt ciężkości ewangelizacji nie tyle na metodach czy środkach, a wewnętrznej dyspozycji Kościoła jako całości i jego poszczególnych członków do kierowania się Ewangelią. Wyraża się to w kilku kluczowych tropach teologiczno-pastoralnych, zawartych we wspomnianej adhortacji.

Pierwszym rysem Franciszkowej wizji ewangelizacji jest radość, co zawarł już w tytule adhortacji. Papież dostrzega wielorakie powody smutku, w jakim żyją ludzie we współczesnym świecie, dlatego głoszenie Ewangelii winno wypływać z serca pełnego radości. Przeciwstawia się także postawie pesymizmu i acedii opanowującej coraz szersze obszary Kościoła ${ }^{19}$. Bez przełamania takiego myślenia trudno się spodziewać, że podejmowany wysiłek ewangelizacyjny przyniesie spodziewane owoce. Z tym łączy się zasadnicze wezwanie Ojca Świętego - do nawrócenia pastoralnego. Chodzi w nim o porzucenie myślenia, którego źródłem jest poszukiwanie własnej wygody i bezpieczeństwa, przez co Kościół staje się zamkniętą twierdzą. Papież Franciszek chce, aby Kościół „wyruszał w drogę” na peryferie świata, by tam odnaleźć człowieka i zanieść mu Chrystusa. Przy tym przestrzega: „Obecnie nie potrzeba nam «zwyczajnego administrowania». Bądźmy we wszystkich regionach ziemi $\mathrm{w}$ "permanentnym stanie misji»" ${ }^{20}$. Kościół nie powinien zatem przeradzać się w skostniałą instytucję reprezentowaną przez „biurokratów” łaski, ale we wspólnotę otwartą na działanie Ducha Świętego, tworzącą żywą komunię wiary i miłości oraz pełną zapału misyjnego. Ewangelizatorzy powinni żyć tak blisko swoich owiec, aby nosili na sobie ich „zapach”21.

Kolejnym ważnym tropem ewangelizacji przekazanym przez papieża Franciszka pozostaje kwestia języka przepowiadania, w tym jego treści. Obrazowa wyjaśnia to przykład podany przez Ojca Świętego:

jeśli jakiś proboszcz podczas roku liturgicznego mówi dziesięć razy o wstrzemięźliwości, a tylko dwa lub trzy razy o miłości czy sprawiedliwości, dochodzi do dysproporcji ${ }^{22}$.

To ukazuje, że można w Kościele głosić teologicznie poprawną naukę, a jednocześnie tworzyć wrażenie oddalenia się od ducha Ewangelii. Wyzwaniem pozostaje teologiczny żargon kaznodziejów, który w wielu wypadkach pozbawia słuchaczy

zakres pojęcia nowej ewangelizacji wyraźnie pokrywa się ze stosowanym prze niego określeniem ewangelizacja.

19 Zob. Franciszek, Evangelii gaudium, 1-10, 81-86.

20 Tamże 25.

21 Por. tamże 24.

22 Tamże 38. 
możliwości zrozumienia głoszonego słowa ${ }^{23}$. Kładąc nacisk na przystępność i obrazowość języka przepowiadania (homiletycznego i katechetycznego), Franciszek podkreśla wartość kerygmatu:

Odkryliśmy, że także w katechezie fundamentalną rolę odgrywa pierwsze przepowiadanie lub „kerygma”, która powinna zajmować centralne miejsce w działalności ewangelizacyjnej i w każdej próbie odnowy kościelnej ${ }^{24}$. I dodaje: Nie należy myśleć, że w katechezie rezygnuje się z kerygmy na rzecz formacji, która miałaby być bardziej „solidna”. Nie ma nic bardziej solidnego, bardziej głębokiego, bardziej pewnego, bardziej treściwego i bardziej mądrego niż takie orędzie ${ }^{25}$.

Przy tym nie oznacza to odrzucenia pełnego przekazu depozytu wiary, ale nadanie mu znaczenia spotkania z osobą Boga, który objawia się jako miłość i przynosi człowiekowi ofertę duchowego wyzwolenia. Zatem kaznodzieje i katecheci nie powinni zapominać, iż wypełniając misję głoszenia słowa winni koncentrować uwagę słuchaczy na przyjęciu Jezusa Chrystusa za Mistrza i Pana. Wszelkie prawdy wiary i stawiane wiernym wymogi moralne powinny być temu podporządkowane.

Jeszcze jeden trop, na który zwrócił uwagę papież Franciszek w swojej adhortacji to duchowość misyjna. Polega ona na łączeniu modlitwy z pracą na rzecz ewangelizacji i przemiany świata. Duchowość, która nie prowadzi do innych - zauważa Ojciec Święty - jest nieporozumieniem. Może ona przybierać postać „duchowości światowej”, która inspirowana pozorną religijnością, a nawet troską o Kościół, koncentruje się na szukaniu chwały ludzkiej, a nie Boga:

Niech Bóg nas wybawi od Kościoła światowego pod duchowymi i duszpasterskimi przykrywkami! Tę duszącą światowość można leczyć, kosztując czystego powietrza Ducha Świętego, uwalniającego nas od pozostania skoncentrowanymi na nas samych, ukrytymi za religijną fasadą pozbawioną Boga. Nie dajmy się okraść z Ewangelii! ${ }^{26}$

Idea ewangelizacji i nowej ewangelizacji rozwija się w Kościele jako idea odnowy duszpasterstwa już od około 50 lat. Kolejni następcy św. Piotra przyczyniali się do jej ukonkretnienia i pogłębienia. Posiada ona także przełożenie na praktykę pastoralną, uruchamiając wiele inicjatyw na poziomie parafialnym, diecezjalnym i Kościoła powszechnego (np. światowe dni młodzieży) ${ }^{27}$. Jej istotę wyraża ruch polegający na przyjęciu na nowo Ewangelii jako wyznacznika życia i działania

\footnotetext{
23 Por. tamże 41-42, 135-144.

24 Tamże 164.

25 Tamże 165.

26 Tamże 97.

27 Zob. A. Kiciński, Światowe dni młodzieży laboratorium nowej ewangelizacji, w: Nowa ewangelizacja w nowej katechezie, dz. cyt., s. 57-71.
} 
Kościoła w celu budzenia wiary. Wypowiedzi poszczególnych papieży wskazywały perspektywę ewangelizacji, w której powinny harmonijnie współdziałać ze sobą różne wymiary aktywności kościelnej, a wśród nich - katecheza. W różnym stopniu była ona zauważana w wypowiedziach poszczególnych papieży dotyczących ewangelizacji, jednak zawsze jako jeden z kluczowych obszarów realizacji tego dzieła. Więcej wskazań dotyczących sposobu łączenia ewangelizacji z katechezą znalazło się w dokumentach katechetycznych, które na przestrzeni również ostatnich 50 . lat regulowały to zagadnienie.

\section{Ewangelizacja w świetle dokumentów katechetycznych}

W pierwszym dokumencie katechetycznym, jakim jest Ogólna instrukcja katechetyczna, wydana przez Kongregację ds. Duchowieństwa w 1971 roku, pojęcia ewangelizacja i katechizacja są wyraźnie od siebie oddzielone. Ewangelizacja, zgodnie z duchem dokumentów soborowych, łączona jest $\mathrm{z}$ działalnością misyjną i ma służyć zapoczątkowaniu wiary. Z kolei działalność katechetyczna winna zmierzać do rozwinięcia u słuchaczy wiary „żywej, wyraźnej i czynnej” za pomocą głoszonej nauki ${ }^{28}$. Pomimo tego rozróżnienia autorzy dokumentu zauważają potrzebę wprowadzania elementów ewangelizacji do katechezy, zwłaszcza w jej części podsumowującej, aby w ten sposób dynamizować wiarę słuchaczy do działania ${ }^{29}$.

Adhortacja apostolska św. Jana Pawła II Catechesi tradendae z 1979 roku wprawdzie stara się zachować rozróżnienia zawarte w Ogólnej instrukcji katechetycznej, jednak wyraźnie poszerza zakres wzajemnych powiązań, ukazując jednocześnie ich wartość uzupełniającą ${ }^{30}$. Punktem odniesienia dla tego dokumentu pozostaje także adhortacja św. Pawła VI Evangelii nuntiandi z jej już poszerzoną wizją ewangelizacji, której adresatami są także wierni Kościoła. Św. Jan Paweł II zauważa, że w wielu wypadkach adresaci katechezy w krajach o długich tradycjach chrześcijańskich nie mieli doświadczenia pierwszej ewangelizacji. Wymienia przy tym szereg sytuacji, które mogą stanowić tego przyczynę. To prowadzi do wniosku:

...że katecheza często winna troszczyć się nie tylko o umocnienie wiary i jej nauczanie, ale z pomocą łaski także o jej stałe rozbudzanie. Niech otwiera serca, nawraca i w ten sposób sprawia, aby ci, którzy dotąd stoją u progu wiary,

\footnotetext{
28 Por. Kongregacja ds. Duchowieństwa, Ogólna instrukcja katechetyczna, 17; J. Charytański, Katecheza jako forma ewangelizacji (Synod Biskupów 1974), w: W. Kubik (red.), Katecheza po Soborze Watykańskim II w świetle dokumentów Kościoła, t. 1, Warszawa 1985, s. 194-195.

29 Por. Kongregacja ds. Duchowieństwa, Ogólna instrukcja katechetyczna, 18.

30 ...między katecheza a ewangelizacją nie ma ani rozdziału, ani przeciwstawności, ani też całkowitej tożsamości, ale jaką́s wewnętrzna więzią łączą się one ze sobą i wzajemnie uzupetniają. Jan Paweł II, Catechesi tradendae, 18. Por. P. Tomasik, Ewangelizacja-katecheza-nauczanie religii $w$ szkole, art. cyt., s. 27.
} 
całkowicie przylgnęli do Jezusa Chrystusa. Troska ta w pewnej mierze określa i ukierunkowuje zakres, język i metodę katechezy ${ }^{31}$.

Jest to w tym wypadku wyraźne wskazanie, że ewangelizacja zmierzająca do budzenia wiary musi być integralnie powiązana ze współczesną katechezą. Przestaje ona być w stosunku do katechezy kwestią drugorzędną, ale nabiera znaczenia kluczowego. Bez ewangelizacji katecheza zaczyna zatracać swoją owocność.

Ogłoszone w 1997 roku przez Kongregację ds. Duchowieństwa Dyrektorium ogólne o katechizacji jeszcze wyraźniej osadziło katechezę w perspektywie ewangelizacyjnej, co znalazło swoje odbicie w tytule części pierwszej tego dokumentu: „Katecheza w misji ewangelizacyjnej Kościoła”. W 46. punkcie Dyrektorium zawarte zostało sformułowanie definiujące Kościół jako społeczność powołaną do ewangelizacji, co wyraża się w głoszeniu, świadectwie, nauczaniu, sprawowaniu sakramentów, miłości braterskiej oraz „czynieniu uczniami” jedynego Mistrza ${ }^{32}$. Było to przywołaniem słów papieża św. Pawła VI z Evangelii nuntiandi i potwierdzeniem, że najbardziej „globalną wizją” posłannictwa Kościoła jest ewangelizacja. Ona sama została opisana w kategoriach procesu posiadającego wieloczłonową strukturę. Proces ewangelizacji ożywiany działaniem Ducha Świętego obejmuje:

- przekształcanie porządku doczesnego i kultury przez ducha ewangelicznej miłości;

- dawanie świadectwa nowego sposobu życia;

- głoszenie Ewangelii i wzywanie do nawrócenia;

- katechizację połączoną z sakramentami wtajemniczenia;

- ożywianie ducha komunii, wychowanie w wierze, przystępowanie do sakramentów, posługę miłości;

- zaangażowanie misyjne . $^{33}$.

W procesie ewangelizacji autorzy dokumentu wskazali trzy „momenty istotne” procesu ewangelizacji, powiązane z określonymi jej adresatami:

- działanie misyjne wobec niewierzących lub obojętnych religijnie;

- działanie katechetyczno-wtajemniczające dla wybierających Ewangelię lub potrzebujących odnowienia swego wtajemniczenia;

- działanie duszpasterskie dla osób dojrzałych w wierze ${ }^{34}$.

Owe istotne momenty można traktować także jako etapy w dojrzewaniu wiary, ponieważ można tu dostrzec doświadczenie jej przyjęcia, katechetyczne pogłębienie, ukierunkowane na wtajemniczenie sakramentalne oraz stabilizację w postaci udziału w życiu wspólnoty eklezjalnej.

Katecheza została przez autorów Dyrektorium wpisana w dynamikę ewangelizacji, ale też stanowi jej niezbędny element. Z jednej strony ewangelizacja obejmuje

31 Jan Paweł II, Catechesi tradendae, 19.

32 Por. Kongregacja ds. Duchowieństwa, Dyrektorium ogólne o katechizacji, 46.

33 Zob. tamże 48.

34 Zob. tamże 49. 
wiele działań, wśród których wymienia się katechezę. Z drugiej - sama ewangelizacja, jak czytamy w Dyrektorium, bez katechezy nie osiągnie trwałych efektów. Skoro jej celem jest poznanie Jezusa Chrystusa, przylgnięcie do Niego i wybór drogi stałego nawrócenia, to osiągnięcie tego wymaga czasu i podjęcia drogi katechizacji ${ }^{35}$. Podkreślenie nieodzowności katechezy w procesie ewangelizacji posiada dodatkowe znaczenie, ponieważ w niektórych środowiskach mogłaby się pojawić pokusa bagatelizowania wartości pełnego przekazu depozytu wiary. Wprawdzie w Dyrektorium priorytetem jest ewangelizacja, jednak jednym z kluczowych motywów powstania tegoż dokumentu było ukazanie Katechizmu Kościoła Katolickiego jako narzędzia katechizacji. Stąd w tym miejscu znajduje się stwierdzenie, iż katechezę należy uważać za pierwszorzędny moment w ewangelizacji. W tle tychże rozważań kryło się także pytanie o to, czy nie należy dążyć do zmiany koncepcji katechezy, aby nadać jej jednoznacznie charakter ewangelizacyjny. W wypowiedziach katechetyków na ten temat przeważał jednak postulat utrzymania właściwej proporcji, aby zachowując istotę przekazu katechetycznego, nadać mu jednocześnie cechy ewangelicznej autentyczności, głównie poprzez osobiste świadectwo wiary katechety ${ }^{36}$.

Wydane cztery lata później Dyrektorium katechetyczne Kościoła katolickiego $w$ Polsce posiada rozwinięcie idei powiązania katechezy z ewangelizacją. Wskazano w nim, że ewangelizacja obok nauczania, wychowania i wtajemniczania, jest kolejną istotną funkcją katechezy w obecnych czasach ${ }^{37}$. Jest to zupełnie nowe spojrzenie na katechezę, jednak domagające się dalszego doprecyzowania. W dalszej części polskiego Dyrektorium przypomniano najważniejsze wskazania Dyrektorium ogólnego o katechizacji, a następnie nakreślono, na czym powinna polegać katecheza ewangelizacyjna:

- na przypominaniu podstawowych elementów wiary;

- na inspirowaniu do autentycznego nawrócenia;

- na pogłębianiu świadomości co do orędzie chrześcijańskiego w kontekście zastrzeżeń, jakie padają pod jego adresem ze strony świata;

- na wspieraniu w przeżywaniu Ewangelii w życiu codziennym;

- na pobudzaniu do potwierdzania chrześcijańskiej nadziei;

- na inspirowaniu do realizacji powołania misyjnego ${ }^{38}$.

35 Zob. tamże 53, 56, 63-64.

36 Zob. tamże 64; P. Goliszek, Katecheza nowoewangelizacyjna, w: Nowa ewangelizacja w nowej katechezie, dz. cyt., s. 118-122; W. Osial, Dyrektorium ogólne o katechizacji a Katechizm Kościoła Katolickiego, „Studia Katechetyczne” 13(2017), s. 42-44.

37 Zob. Konferencja Episkopatu Polski, Dyrektorium katechetyczne Kościoła katolickiego w Polsce, 20; A. Offmański, Ewangelizacyjny charakter katechezy w ujęciu „Dyrektorium katechetycznego Kościoła katolickiego w Polsce", w: S. Dziekoński (red.), Przesłanie dokumentów katechetycznych Kościoła w Polsce, Warszawa 2003, s. 78-79.

38 Zob. Konferencja Episkopatu Polski, Dyrektorium katechetyczne Kościoła katolickiego w Polsce, 56. 
Nie tworzy to zasadniczego novum co do koncepcji katechezy (struktury, metod czy treści), za to przypomina o jej praktycznym ukierunkowaniu na doświadczanie wiary w Chrystusa.

Katecheza ewangelizacyjna, połączona w miarę potrzeby z pierwszym głoszeniem Ewangelii i pre-katechezą, stanowi wymóg nowej ewangelizacji. Powinna ona uświadamiać uczniom ich własne życiowe sytuacje, pomóc im w określeniu sensu i odkrywaniu religijnego wymiaru przeżywanych przez nich problemów ${ }^{39}$.

Miejscem realizacji katechezy ewangelizacyjnej ma być przede wszystkim szkoła publiczna oraz szkoła katolicka, w których wielu uczniów ma jedyną szansę na kontakt z ewangelicznym orędziem Jezusa Chrystusa i Jego świadkami - katechetami i uczniami wierzącymi ${ }^{40}$. Dzięki harmonijnej współpracy katechetów z pozostałymi nauczycielami oraz rodzicami szkoła może stawać się środowiskiem, w którym rozwijane są wartości chrześcijańskie w zgodzie ze szkolnym programem edukacyjno-wychowawczym. Wiele zatem zależy od inwencji samych katechetów oraz od możliwości, jakie dają środowiska, w których katechizują. Autorzy dokumentu nie pozostawiają wątpliwości co do tego, że w szkole pełna ewangelizacja nie jest możliwa. Podobnie jak funkcja wtajemniczania, może ona być tam realizowana jedynie częściowo, stąd niezbędne jej dopełnienie powinno odbywać się w parafii ${ }^{41}$.

Po upływie 23 lat od ogłoszenia Dyrektorium ogólnego o katechizacji zostało wydane Dyrektorium o katechizacji, będące spojrzeniem na aktualne zadania i wyzwania stojące przed współczesną katechezą w warunkach zmieniającego się świata. Tym razem za redakcję tego dokumentu odpowiada Papieska Rada ds. Krzewienia Nowej Ewangelizacji, w której kompetencjach katechizacja znajduje się od 2013 roku. Już fakt strukturalnego przyporządkowania katechezy dykasterii odpowiadającej za dzieło nowej ewangelizacji wskazuje na zasadniczą nowość Dyrektorium. Podkreśla ono jeszcze ściślejsze powiązanie tych dwóch dziedzin posługi słowa w Kościele. Już we wstępie do tego dokumentu zwrócono uwagę na konieczność zharmonizowania katechezy ze wskazaniami zawartymi w adhortacji papieża Franciszka Evangelii gaudium, zwłaszcza z zasadą pierwszeństwa kerygmatu w posłudze słowa ${ }^{42}$.

Podobnie jak w Dyrektorium ogólnym o katechizacji pierwsza część najnowszego Dyrektorium nosi tytuł „Katecheza w ewangelizacyjnej misji Kościoła”. W tym dokumencie ewangelizacja została jednak opisana nieco szerzej. Położono tu nacisk nie tyle na nauczaniu, co na uobecnianiu i głoszeniu Jezusa Chrystusa. Celem ewangelizacji jest doprowadzenie do zbawienia (lub, jak to wyraża teologia wschodu,

39 Tamże 56.

40 Por. tamże 57, 84, 94.

41 Por. tamże 13; A. Offmański, Ewangelizacyjny charakter katechezy ..., art. cyt., s. 80-81.

42 Zob. Papieska Rada ds. Krzewienia Nowej Ewangelizacji, Dyrektorium katechetyczne, Wstęp. 
do przebóstwienia $)^{43}$. Proces ewangelizacji został przedstawiony w sposób analogiczny, jak miało to miejsce we wcześniejszym Dyrektorium. Elementem, na jaki zwrócono uwagę $\mathrm{w}$ omawianym dokumencie, stała się ewangelizacja $\mathrm{w}$ świecie współczesnym. Autorzy dostrzegli, że Kościół znalazł się wobec „nowego etapu ewangelizacji" polegającego na jeszcze szerszym otwarciu się na odnawiające działanie Ducha Zmartwychwstałego. Chodzi w nim o dokonanie „duszpasterskiego nawrócenia” i o podjęcie przez Kościół wysiłku „wyruszenia w drogę”. Powinno to się ukonkretnić w trzech obszarach - duszpasterstwa zwyczajnego osób wierzących (aby coraz lepiej odpowiadali życiem na miłość Boga); środowiska ochrzczonych, którzy nie żyją zgodnie z wymogami chrztu św. (przekazać im nowymi metodami i językiem prawdę o Chrystusie w duchu dialogu i przyjaźni); środowiska nie znających Chrystusa lub odrzucających Go (w duchu misyjnym przekazywać kerygmat o Chrystusie $)^{44}$.

W najnowszym Dyrektorium nakreślone zostały cechy katechezy rozwijającej ducha nowej ewangelizacji. Zwrócono w tym miejscu uwagę na modelowy charakter „katechezy misyjnej”. Chrystusowy nakaz misyjny pozostaje stale aktualnym wzorcem każdego działania Kościoła o charakterze duszpasterskim. Cechą odpowiadającej temu modelowi jest katecheza wychodząca (zbliżająca się) do człowieka. Jej efektem powinno być także kształtowanie chrześcijan świadomych tego, że mają stawać się świadkami i misjonarzami wiary ${ }^{45}$. Następnym rysem katechezy „nowo ewangelizacyjnej” wymienionym w Dyrektorium jest postawa miłosierdzia. Praktykowanie miłosierdzia - jak zaznaczają autorzy dokumentu - samo w sobie jest autentyczna katechizacją46. W świadomości katechizujących powinna ona być służbą miłosierdzia względem duszy (oświecaniem umysłu i serca) oraz ciała, a także kształtować u uczniów gotowość stawania się miłosiernym na wzór Ojca. Trzecią cechą tejże katechezy należy czynić styl dialogu w duchu szacunku i otwartości na drugą osobę. Naśladując rozmowę Jezusa z Samarytanką poprzez pytania i podpowiedzi katecheza ma zmierzać do budzenia w katechizowanym pragnienia zaczerpnięcia z źródła wody żywej ${ }^{47}$.

Nowym aspektem katechezy, ukazującym jej naturę, jest w świetle Dyrektorium o katechizacji jej związek z kerygmatem. Oznacza to, że ma być przede wszystkim głoszeniem wiary oraz przekonywaniem, dlaczego warto wierzyć. W jej centrum ma być osoba Jezusa Chrystusa, który jest podmiotem (i treścią) kerygmatu, bo tylko On zna serce człowieka i jest w stanie je wypełnić. Ponadto przyjęcie kerygmatu jako podstawowej optyki katechezy powinno nadać jej następujące charakteryzujące ją cechy:

\footnotetext{
43 Zob. tamże 29-30.

44 Zob. tamże 38-41.

45 Zob. tamże 49-50.

46 Tamże 51.

47 Por. tamże 53-54.
} 
...żeby wyrażała zbawczą miłość Boga uprzednią w stosunku do moralnych i religijnych zobowiązań; żeby nie narzucała prawdy i odwoływała się do wolności; żeby miała pewne cechy radości, bodźca, żywotności i harmonijnej pełni nie sprowadzającej przepowiadania do kilku doktryn, czasem bardziej filozoficznych niż ewangelicznych". Katecheza, jako echo kerygmatu, powinna podkreślać takie elementy, jak: charakter propozycji; jakość narracyjna, uczuciowa i egzystencjalna; wymiar świadectwa wiary; nastawienie na relację; wymowa zbawcza ${ }^{48}$.

Zaproponowana wizja katechezy nie stanowi zasadniczej nowości. Istotniejsze wydaje się jednak wskazanie, że może się ona „wewnętrznie odnawiać” przez powrót do prostoty przekazu (kerygmatycznego). Tym, co nieuchronnie powoduje jej „starzenie się”, jest proces wypracowywania uniwersalnych schematów, programów, algorytmów. Starzenie się katechezy objawia się także w języku, który łatwo może przybierać formę niezrozumiałego dla katechizowanych teologicznego żargonu. Dochodzi do tego różnica mentalności pomiędzy katechizującym i katechizowanymi. Wskazania Dyrektorium zdają się zatem być rodzajem memento do katechetów, aby katechizując nie tracili wrażliwości na rzeczy najważniejsze i na prostotę przekazu. Katecheza (szkolna i parafialna) nie powinna ograniczać się do dydaktyzmu oraz moralizmu, ale być spotkaniem i wspólnym szukaniem Boga oraz tego, co jest Bożym światłem pozwalającym zrozumieć siebie, drogę, którą wędrujemy i cel, do którego wszyscy zmierzamy.

\section{Podsumowanie}

To, że refleksja nad odnową katechezy jest podejmowana już od pięćdziesięciu lat, potwierdza wysiłek Kościoła w tym względzie. Kolejne dekady tych starań dostarczały nowych doświadczeń, dzięki którym pogłębieniu ulegało spojrzenie na istotę katechezy. Dokumenty katechetyczne w odpowiedzi na nauczanie kolejnych papieży coraz mocniej podkreślały związek katechizacji i ewangelizacji na zasadzie komplementarności. Katecheza musi coraz bardziej czerpać inspiracje z ewangelizacji i służyć ewangelizacji, a jednocześnie ewangelizacja nie może obyć się bez systematycznej formacji realizowanej za sprawą katechizacji. Tym, co znajduje się w punkcie stycznym pomiędzy tym działaniami, jest wzbudzanie i rozwój wiary. Jej zrodzenie powinno być efektem doświadczenia ewangelizacji, zaś katecheza - zakładając wiarę u słuchaczy - ma ją pogłębiać i ugruntowywać. Ponieważ nie zawsze panuje taka sytuacja, katecheza musi przybierać kształt ewangelizacji lub do niej prowadzić.

48 Tamże 59. 
Nie ma wątpliwości, że żadne dyrektorium nie dokona odnowy katechezy. Ono może pomóc osobom odpowiedzialnym za katechezę na różnych szczeblach struktury kościelnej właściwie ukierunkowywać wysiłki podejmowane w tej materii. Skuteczność odnowy katechetycznej zależy zatem od ludzi Kościoła, a szczególnie od katechizujących. Oni to nadają "jakość" prowadzonej przez siebie katechezie, odciskając przy tym swój osobisty ślad. Im bardziej w ich życiu dokonało się osobiste spotkanie z Chrystusem połączone z wyborem Ewangelii jako drogi życia, tym owocniej mogą oni pełnić rolę świadków wiary. Innymi słowy, katechizujący powinni być pierwszymi „ewangelizowanymi”. Ma to polegać nade wszystko na stałym wysiłku odnawiania swego myślenia, na mentalnej przemianie, na pokornym poddawaniu się działaniu Ducha Świętego, na odczytywaniu znaków czasu, na wychodzeniu do katechizowanych i budowaniu autentycznych relacji z nimi.

Reformy katechezy nie dokonają sami katecheci (choćby byli ludźmi heroicznej wiary), ale cała wspólnota Kościoła, poczynając od jego pasterzy. Właściwym miejscem katechezy jest żywa wspólnota wiary, w której realizowane są wszystkie podstawowe aspekty działalności eklezjalnej (liturgia, świadectwo, diakonia, misje, miłosierdzie). Funkcjonowanie takiej wspólnoty przyczynia się do powstawania kultury życia chrześcijańskiego, polegającego na przyjmowaniu ewangelicznych wymagań. Dopiero żywa wspólnota wiary jest w stanie stać się oparciem dla katechetów w ich misji. Z tym postulatem łączy się także kolejny - o katechezę parafialną, w tym adresowaną do dorosłych. Kościół w Polsce wciąż nie znajduje sposobu, aby zadawalająco rozwiązać ten problem. Inną bolączką polskiej katechezy jest także niski poziom religijności w rodzinach. Choć o tym problemie mówi się już od lat, to jednak sytuacja pod tym względem niewiele się zmienia. Nie powinno to jednak zwalniać katechetyków, pastoralistów oraz specjalistów innych nauk (np. socjologii, antropologii, badaczy kultury) od podejmowania wspólnego i wieloaspektowego studium nad sposobami rozwiązywania wyzwań, jakie stają przed współczesnym Kościołem.

Słowa kluczowe: katecheza, ewangelizacja, odnowa Kościoła, nawrócenie pastoralne, kerygmat.

\section{Summary}

Catechesis renewal is a constant concern of the Church. The development of evangelization and new evangelization in the Church have had an impact on the direction and nature of this renewal. Since the Vatican Council II subsequent popes have been developing the concepts of evangelization consistently. Catechesis and evangelization have become intrinsically linked under the influence of their preaching. They complement each other as contemporary catechesis requires evangelical elements. Evangelization cannot do without a solid catechetical formation, either. The guidelines referring to catechesis renewal included in the catechetical documents should become an inspiration for those who are responsible 
for catechesis process in Poland and should trigger the activities which will fruitfully combine the lives of church communities with evangelization and catechesis.

Keywords: catechesis, evangelization, Church renewal, pastoral conversion, kerygma.

\section{Riassunto}

Il rinnovamento della catechesi è un pensiero costante della Chiesa. La direzione e la natura di questo rinnovamento sono stati fortemente influenzati dallo sviluppo dell'idea di evangelizzazione in generale e di nuova evangelizzazione nella Chiesa. A partire dal Concilio Vaticano II, i pontefici che si susseguivano hanno costantemente incrementato concetti di evangelizzazione. Sotto il segno del loro insegnamento si è instaurato un legame sempre più profondo tra catechesi ed evangelizzazione. Ha un profilo di integrazione complementare, perché la catechesi contemporanea necessita di elementi evangelizzatori. Allo stesso modo, l'evangelizzazione non può fare a meno di una solida formazione catechetica. Le indicazioni riguardanti il rinnovamento della catechesi contenute nei documenti catechetici dovrebbero esortare i responsabili della catechesi in Polonia, per avviare attività volte a collegare fruttuosamente la vita delle comunità ecclesiali con l'attività evangelizzatrice e la catechesi.

Parole chiavi: catechesi, evangelizzazione, rinnovamento della Chiesa, conversione pastorale, kerigma.

\section{Bibliografia}

Benedykt XVI, Ubicumque et semper.

Biela B., Typy i metody ewangelizacji w świetle współczesnego nauczania Magisterium Ecclesiae, „Studia Nauk Teologicznych” 10(2015), w: https://czasopisma.kul.pl/snt/article/ view/6257/5860 (dostęp 1.03.2021).

Charytański J., Katecheza jako forma ewangelizacji (Synod Biskupów 1974), w: Kubik W. (red.), Katecheza po Soborze Watykańskim II w świetle dokumentów Kościoła, t. 1, Warszawa 1985.

Franciszek, Evangelii gaudium.

Goliszek P., Katecheza nowoewangelizacyjna, w: Mąkosa P. (red.), Nowa ewangelizacja $w$ nowej katechezie, Lubin 2013.

Kiciński A., Światowe dni młodzieży laboratorium nowej ewangelizacji, w: Mąkosa P. (red.), Nowa ewangelizacja w nowej katechezie, Lubin 2013.

Konferencja Episkopatu Polski, Dyrektorium katechetyczne Kościoła katolickiego w Polsce. Kongregacja ds. Duchowieństwa, Dyrektorium ogólne o katechizacji.

Kongregacja ds. Duchowieństwa, Ogólna instrukcja katechetyczna.

Lewek A., Idea i sens nowej ewangelizacji, „Studia Theologica Varsaviensia” 32(1994)2.

Murawski R., Stosunek ewangelizacji do katechezy w dziejach katechezy, w: Dziekoński S. (red.), Ewangelizować czy katechizować?, Warszawa 2002.

Nauczanie religii w Polsce (w 2019 r.), w: https://www.ekai.pl/nauczanie-religii-w-polsce/ (dostęp 1.03.2021). 
Offmański A., Ewangelizacyjny charakter katechezy w ujęciu „Dyrektorium katechetycznego Kościoła katolickiego w Polsce", w: Dziekoński S. (red.), Przesłanie dokumentów katechetycznych Kościoła w Polsce, Warszawa 2003.

Osial W., Dyrektorium ogólne o katechizacji a Katechizm Kościoła Katolickiego, „Studia Katechetyczne" 13(2017), s. 42-44.

Osial W., Wezwanie Benedykta XVI do nowej ewangelizacji w świetle listu apostolskiego "motu proprio" Ubicumque et semper ustanawiajacego Papieska Radę Ds. Krzewienia Nowej Ewangelizacji, „Warszawskie Studia Teologiczne” 24(2011)1.

Papieska Rada ds. Krzewienia Nowej Ewangelizacji, Dyrektorium katechetyczne.

Puchalski G., Ewangelizacja i nowa ewangelizacja w nauczaniu Kościoła, w: Mąkosa P. (red.), Katecheza ewangelizacyjna. Poszukiwania koncepcji, Lublin 2021.

Śmigiel W., Specyfika i zadania nowej ewangelizacji, w: Mąkosa P. (red.), Nowa ewangelizacja w nowej katechezie, Lubin 2013.

Jan Paweł II, Catechesi tradendae.

Jan Paweł II, Ecclesia in Europa.

Paweł VI, Evangelii nuntiandi.

Tokarek S., Ewangelizacja wedtug Benedykta XVI, „Studia Teologiczno-Historyczne Śląska Opolskiego" (2013).

Tomasik P., Ewangelizacja-katecheza-nauczanie religii w szkole, w: Dziekoński S. (red.), Ewangelizować czy katechizować?, Warszawa 2002. 